\title{
ON THE BACK COVER:
}

NEW: A LETTER FROM WALT TO LOUISA WHITMAN-When Edwin Haviland Miller compiled his five-volume edition of Walt Whitman's Correspondence (New York: New York University Press, 1961-1969), he hoped bravely (his word) that he had "completed" his task; however, he not only added to his 2800 letters more than 60 additional ones in the Addenda in Vol. 5 (1969), but he published a Supplement in 1977, with 90 further letters. As readers of the Walt Whitman Review and the Walt Whitman Quarterly Review are aware, there is no end, for we have since published, mainly on the back cover and mainly from the Feinberg Collection-Library of Congress, 17 more pieces of correspondence. The latest one-see the back cover-printed here through Mr. Feinberg's kindness as usual, is from the poet to his sister-in-law (she was George's wife) Louisa Orr Whitman (1842-1892) in Burlington, New Jersey. It concerns Mrs. J. J. (Margaret or Maggie) Goodenough, who took care of Walt's incapacitated brother Edward, and payment of $\$ 16$ for his board, recorded in Whitman's Daybooks (New York: New York University Press, 1978), 2:422. Reference in the letter is also made to sister Hanna Louisa Heyde, who wrote to the poet in New York, where he made, on 14 April 1887, an address on Abraham Lincoln, followed the next day by a reception in the Westminster Hotel. (See the account of this from The Evening Sun, kept by Whitman in his Daybooks, 2:417-420n.) 